\title{
O Elogio da Dialética: Algumas observações sobre o teatro engajado da Companhia do Latão
}

Gabriel Alves de Campos ${ }^{1}$

Editado pela Cosac Naify em 2008, o livro Companhia do Latão 7 peças merece ser lido. Talvez mais do que isso. Como se trata de um grupo que tem como base a correlação entre teoria e prática, os textos aqui reunidos poderiam ser montados e discutidos até por outras companhias teatrais. Articulando problema social e problema de estilo, o Latão, na época tendo à frente Sérgio de Carvalho e Márcio Marciano, desarma as estruturas do drama e revela através dele as contradições do processo social brasileiro. Como o próprio diretor afirma, "a politização do olhar pede mais que uma forma estética específica, pede uma construção rigorosamente dialética, em que a peça seja um problema que estimule o público à ação intelectual, imaginativa, sensível. Em termos brechtianos, a cena dialética torna o espectador um produtor" ${ }^{2}$. Afinando texto e contexto, as peças presentes no livro formam uma oposição à imagem pronta da vida, seus padrões estéticos e suas formulações sensíveis. Lendo a contrapelo, é como se os textos buscassem à moda machadiana certo "sentimento íntimo" através do "influxo modelizante" brechtiano. Esse sentimento peculiarmente nacional está profundamente ligado à estruturação objetiva da sociedade, ou seja, movimenta-se e se realiza por meio das relações sociais, de cuja matriz prática o grupo parte para configurar na cena sua redução estrutural. Ora, é sabido que toda obra tem um sentido ${ }^{3}$, assim como todo espetáculo apresenta um ponto de vista. Ainda segundo Sérgio de Carvalho, "talvez um dos equívocos mais graves que se cometem em arte seja o de achar que as formas são neutras, de que as formas não têm conteúdos em si, de que as formas não são históricas. Quando se encena uma peça dramática, com um herói vencendo continuamente seus

\footnotetext{
${ }^{1}$ Mestrando em Estudos Comparados de Literaturas de Língua Portuguesa da Universidade de São Paulo.

${ }^{2}$ GARCIA, Silvana. (org.). Odisséia do teatro brasileiro. São Paulo: Editora Senac, 2002. P. 99

${ }^{3}$ Cf. JAMESON, Fredric. O inconsciente político: a narrativa com ato socialmente simbólico. Editora Ática: 1992.
} 
obstáculos e se modificando no final, só a estruturação formal dessa peça, sua condução centrada na expectativa do cumprimento do desejo, já contém um sentido ideológico"»4.

O leitor desavisado que se meter a ler os textos do Latão deve ficar atento à maneira como eles compõem um mosaico crítico da situação atual através de um mecanismo de oposição entre o velho e o novo. Mesmo em peças de riso mais escancarado como a "Comédia do Trabalho", que numa primeira leitura parece abusar do ingênuo e do popular, notamos uma crítica frontal e aguda ao complexo cultural e ideológico no qual até segunda ordem estamos metidos, trazendo para o centro da cena (e para além dela) a relação entre arte e sociedade.

Com estudo dramatúrgico calcado no paradigma do trabalho, todas as categorias poéticas do grupo funcionam como categorias políticas, enquanto todas as políticas são poéticas, de modo que essa "politização da estética" reverbera um pouco do Marx dos Manuscritos, quando este afirmava que todos os conceitos filosóficos da teoria marxista são categorias econômicas e sociais, enquanto que todas as categoriais econômicas e sociais de Hegel são conceitos filosóficos. Assim, brincando com categorias estéticas e políticas, estabelecendo um jogo entre palco e platéia, construindo texto e cena simultaneamente, o Latão cria uma dialética do velho e do novo e retoma a luta de classes para fundamentar seu teatro através do risco de se reativar o projeto clássico ${ }^{5}$ de Brecht fora do eixo central de onde ele decorreu. Aliás, a questão do antagonismo social nos textos aparece na forma, e não somente no conteúdo, dos textos da Companhia $^{6}$ sempre como decorrência do debate entre arte e política.

Da mercadoria como universal concreto às suas particularidades na periferia do capitalismo, os capítulos iniciais do livro desenham um pouco da trajetória do grupo e apresentam seu arcabouço teórico para pensar o Método Brecht nos trópicos. Em "Imagens do Brasil", temos três peças que marcam a tentativa de pensar o País na contramão dos apóstolos do progresso. Alinhado com certa tradição crítica da história brasileira $^{7}$, o Latão demarca nesses textos sua visão política na medida em que toma

\footnotetext{
4 GARCIA, Silvana. (org.). Odisséia do teatro brasileiro. São Paulo: Editora Senac, 2002. P. 97

5 Se realmente há em Brecht uma opção de corte clássico, dialeticamente ela, ao se definir, deve incluir nos seus cálculos o risco de neutralização. PASTA, José Antônio. Trabalho de Brecht, São Paulo: Editora 34, 2010. P. 129

${ }^{6}$ Para quem deseja se aprofundar um pouco mais na pesquisa que move seus integrantes pode acessar os estudos no site, na revista Vintém e no jornal Traulito.

${ }^{7}$ Analisando Lima Barreto, Carlos Nelson Coutinho afirma que "o caminho do povo brasileiro para o progresso social - um caminho lento e irregular - ocorreu sem no quadro de uma conciliação com o atraso, segundo aquilo que Lênin chamou "via prussiana" e Gramsci designou "revolução passiva". Ao invés das velhas forças e relações sociais serem extirpadas através de amplos movimentos populares de
} 
uma posição frente aos problemas reais que balizam o debate contemporâneo. À maneira rosenfeldiana, que pensa o teatro "sobretudo [como] um lugar de lucidez, de crítica racional, de discussão intelectual de valores", o grupo orienta seus estudos para uma arte que decanta a experiência histórica, que discute o papel político do teatro e problematiza a ordem naturalizada da forma. Dialeticamente filiado a uma tradição crítica e artística (pode-se, por exemplo, aproximar o grupo à produção teórica de Paulo Arantes ou Roberto Schwarz e/ou aos trabalhos do CPC da UNE ou do Teatro de Arena ${ }^{8}$ ), o Latão procura superar e problematizar tensões passadas à luz do presente, diante de um interesse real cujo pressuposto político e social é a crítica de um movimento histórico que repõe o passado. Justamente contra esse processo de modernização conservadora é que a Companhia desenvolve seu trabalho de pesquisa. Utilizando-se do mecanismo do distanciamento, a cena contrasta com a harmonização das diferenças do mundo mercantil e lança a pergunta no seio da evidência fazendo pulsar as contradições que a ideologia procura manter em repouso.

Observemos duas cenas da peça "O nome do sujeito" e vejamos como a técnica brechtiana é articulada com a realidade brasileira. A questão do sujeito individual próprio da forma dramática -, dono de si mesmo, dotado da capacidade de decidir e agir, aqui encontra seu obstáculo na sociedade escravista. Há inclusive o problema da luta de classes, visto que a colônia era apenas um entreposto comercial e os poucos homens brancos e livres que havia viviam entre o favor e a malandragem. Portanto, o capital não tinha seu antagonista, o proletariado.

massa, como é característico da "via francesa", a alteração social se fez aqui mediante conciliações entre o novo e o velho, [...] mediante um reformismo pelo alto, que exclui inteiramente a participação popular". Por um lado ainda mais preciso, de corte histórico, Roberto Schwarz afirma que "É sabido que a Independência brasileira não foi uma revolução: ressalvadas a mudança no relacionamento externo e reorganização administrativa no topo, a estrutura econômico-social criada pela exploração colonial continuava intacta, agora em beneficio das classes dominantes locais. Diante dessa persistência, era inevitável que as formas modernas de civilização, vindas na esteira da emancipação política e implicando liberdade e cidadania parecessem estrangeiras - ou postiças, antinacionais, emprestadas, despropositadas, etc. conforme a preferência dos diferentes críticos. A diferença da adjetivação indica as contorções do amor-próprio brasileiro (de elite), obrigado a desmerecer em nome do progresso os fundamentos de sua preeminência social, ou vice-versa, opção deprimente nos dois casos. De um lado, tráfico negreiro, latifúndio, escravidão e mandonismo, um complexo de relações com regra própria, firmado durante a colônia e ao qual o universalismo da civilização burguesa não chegava; de outro sendo posto em xeque pelo primeiro, mas pondo-o em xeque também, a Lei (igual para todos), a separação entre público e privado, as liberdades civis, o parlamente, o patriotismo romântico, etc. a convivência familiar e estabilizada entre essas concepções em principio incompatíveis esteve no centro da inquietação ideológico-moral do Brasil oitocentista”.

\footnotetext{
${ }^{8}$ Dos textos de maior aproximação de Roberto podemos citar os estudos sobre Machado de Assis, mas, sobretudo, Cultura e Política e As ideias fora do lugar. De Paulo Arantes o grupo se inspira principalmente no livro Sentimento da Dialética e nos ensaios do livro Zero à Esquerda.
} 
Antonio Lyra, carregando uma caixa de mascate, vê o mendigo caído dando gargalhadas.

ANTÔNIO Alegria, por quê, ó miserável? Até parece que o Imperador decretou um feriado de mil anos. Eu não posso me acostumar.

MENDIGO Dê uma esmolinha, dê.

ANTÔNIO É uma gente que só acha o que ninguém perde.

(Companhia do Latão 7 peças, O nome do sujeito, p. 63).

Mais adiante há outro encontro de Antônio com o Mendigo. Desde os diálogos, passando pela métrica usada no coro (redondilha maior) para compor o song e obter um efeito estético ${ }^{9}$, até a composição da narrativa em que cada cena fala por si, o grupo parece mostrar os impasses da reificação e do valor de troca ${ }^{10}$. Com seu equivalente estético a partir da montagem em uma peça na periferia do capitalismo, em que as relações sujeito/objeto não foram definidas historicamente, a dialética rarefeita ganha um caráter enigmático, mistificador e vem com sinal positivo na forma da ideologia da cordialidade, daí o horror que o brasileiro tem das distâncias, da impessoalidade na relação com o outro.

A formulação marxista que acentua a identidade na diferença ("trigo=ferro") traço do capitalismo - quando assimilada nas relações sociais e interiorizada psicologicamente, termina por anular as possibilidades de realização do sujeito (sob outro ponto de vista, o problema se encontra formulado na lírica de Drummond, por exemplo). A ideia de que "o mesmo é o outro" na sociedade brasileira deixa indefinido o espaço social entre a casa e a rua (público/privado) e reproduz os efeitos da esfera econômica na vida social; a objetivação da subjetivação.

Repare como o Latão trabalha esteticamente a contradição brasileira da ideia de liberdade tal como Locke a pensava, isto é, como propriedade sobre si.

[...] numa ruela do Recife, Antônio avista uma moeda deixada no chão, jogada ao lado do mendigo que dorme. Pega a moeda e põe no bolso. Quando começa a sair, o mendigo acorda de um sonho.

\footnotetext{
9 Segundo Anatol Rosenfeld, "se Brecht tende a teatralizar a literatura ao máximo - traduzindo nas suas encenações os textos em termos de palco - por outro lado procurou também "literarizar" a cena". ROSENFELD, Anatol. O Teatro Épico. São Paulo: Perspectiva, 2004. P. 158.

10 " [...] Tomemos duas mercadorias, por exemplo, trigo e ferro. Qualquer que seja a proporção em que se troquem, é possível sempre expressá-la com uma igualdade em que dada quantidade de trigo se iguala a alguma quantidade de ferro, por exemplo, 1 quarta de trigo $=n$ quintais de ferro. Que significa essa igualdade? Que algo comum, com essa mesma grandeza, existe em duas coisas diferentes, em uma quarta de trigo e em $n$ quintais de ferro. As duas coisas são, portanto, iguais a uma terceira, que, por sua vez, delas difere. Cada uma das duas, como valor-de-troca, é reduzível, necessariamente, a essa terceira". MARX, Karl. O Capital. Rio de Janeiro: Civilização Brasileira, 2008. P. 59.
} 
MENDIGO [ainda tomado pelas imagens do sonho] Foge não, meu garotinho, foge não, fica aí, que eu vou pegar meu cavalo castanho-escuro e vou cavalgar, te atentar e, quando alcançar, tomar pelo rabo, eu vou. [tenta se erguer e cai]

ANTÔNIO Que coisa triste, meu Deus. Ei, mulato, tu não podes desistir assim dos dias, ergue-te, homem, tu és um mulato forte. Assim tu te tornas uma vala, um vazio. [Ergue o mendigo] Devias ter ficado com teu senhor, ao menos terias o que comer.

MENDIGO Eu sou livre.

ANTÔNIO Ninguém é livre nesta terra.

MENDIGO Eu sou.

ANTÔNIO És?

MENDIGO Eu me herdei.

ANTÔNIO Espera. Eu vou te favorecer, só porque tens feição de sujeito honesto. Toma, compra uma sela para teu cavalo. [Entrega a moeda que tinha roubado há pouco].

MENDIGO [aproxima o rosto para poder ver a moeda] É o Imperador, ele quer ter uma conversa comigo.

CORO [canta] Ando roto e esfarrapado.

É meu gosto andar assim

Pra gastar com as mulatinhas

Ninguém tenha dó de mim

Todos tenham, ninguém tenha,

Só Deus tenha dó de mim.

(Companhia do Latão 7 peças, O nome do sujeito, p. 67).

Acertando as contas com a História e historicizando os conceitos e as formas artísticas no interior do sistema produtivo que sustenta a esfera da cultura, os textos presentes no livro são uma tentativa viva, constante, de compreender a feição concreta e abstrata da sociedade, opondo e unindo forma social e matéria histórica para revelar o caráter de falsa promessa da ideologia.

É sabido que a pauta da realidade é dada pelo capitalismo. Porém, é certo que não podemos nos paralisar diante do axioma, afinal, na luta entre o velho e o novo, Brecht dizia que "só poderemos descrever o mundo atual para o homem atual na medida em que descrevermos como um mundo passível de modificação"11.

11 BRECHT, Bertold. Estudos sobre teatro. Rio de Janeiro: Nova Fronteira, 2005 P. 21 


\section{Perspectiva historicizante}

As verdadeiras obras de arte são somente aquelas cujo conteúdo e forma se revelam completamente idênticos.

Hegel

Para o filósofo Walter Benjamin, escrever a história significava dar às datas a sua fisionomia. O trabalho de Brecht caminha na mesma direção. O problema central que ocupa a historiografia passa a ser parte constituinte do instrumental brechtiano: como contar uma história, histórias, a História? Para compreender a dimensão de seu trabalho, é necessário pensar alguns de seus principais conceitos à luz da história do teatro. Isto é, compreender os reflexos da vida material na cultura. Perceber de que maneira a arte sofre uma interferência do espaço e do tempo em que ela está inserida. E justamente essa "impureza vital”, como dizia Lúcia Miguel Pereira, é que faz com que uma obra não seja fechada em si mesma e nem constituía um campo autônomo da sociedade, mas esteja aberta para o mundo. A imagem cênica de Brecht é mais do que conceber ideias em imagens e imagens em ideias, é algo que vai além da representação, salta para realidade e constitui uma relação crítica entre a cena e o espectador, um trânsito vivo entre palco e platéia através de uma forma artística captada sensorialmente a que Hegel chamou de o "luzir sensível da ideia". Daí a necessidade estrutural de que as peças lidas ganhem vida na imaginação do leitor ou do ator. $\mathrm{Na}$ dramaturgia brechtiana, a recepção da obra já é parte integrante de sua composição e a imagem construída da realidade não se encerra na cena, mas aponta para fora dela, pois pensa a teoria do teatro com vistas a uma prática social. Há nesse movimento uma tentativa de ativar o espírito crítico do espectador por meio da desautomatização da percepção. É como se através desse efeito de negação da ilusão o dramaturgo alemão provocasse um choque na prótese do desejo do espectador. Ali, onde bate o coração que identifica herói e público, o "eis aí" da história - núcleo do épico - aparece de modo premeditado como parte do projeto clássico que seu teatro pretende alcançar. Segundo José Antônio Pasta, “[...] ao exercício dessa premeditação, que hiperbolicamente afirma e nega o trabalho na linguagem, vimos chamando "abrir-se para o mundo", 12 .

Enfim, uma obra que se desloca dentro do complexo ideológico que abarca cultura, economia e sociedade e que, ao se deslocar e tocar tudo que está à sua volta,

12 PASTA, José Antônio. Trabalho de Brecht, São Paulo: Editora 34, 2010. P. 40 
termina por suprimir a si mesma e evoca um chamado à transformação social. Sendo uma arte preocupada com a esfera pública, trata de assuntos políticos, faz o exame das relações sociais, dá caráter histórico ao que é colocado como natural, em que entender significa compreender. Com relação à dramaturgia, que é propriamente nosso foco de interesse,

A teoria brechtiana do teatro coloca o problema do texto em termos novos. Não se trata mais, com efeito, de saber que importância lhe deve ser atribuída em relação aos outros elementos do espetáculo, nem de definir um esquema de subordinação mais ou menos acentuada desses outros elementos do texto. Brecht interroga-se sobre a função do texto dentro de um conjunto da realização cênica, sobre as possibilidades que ele oferece de representar diversos significados, seja por oposição àquilo que o palco deixa amostra, seja por adaptação (ou inadaptação) a um público particular.

(ROUBINE, Jean-Jacques. A Linguagem de Encenação Teatral. Rio de Janeiro: Jorge Zahar Ed., 1998 P. 66)

Com um teatro voltado para as dimensões decisivas da vida moderna, o épico aparece como a antítese do drama, como a necessidade formal de apreender novos conteúdos, questionando o teatro como uma instituição moral.

Veja o quadro abaixo ${ }^{13}$.

O palco corporifica uma ação

Envolvimento (consome sua atividade)

Possibilita sentimentos

Vivência

O espectador é transportado para dentro da ação; identifica-se

Trabalha-se com a sugestão

Conservam-se as sensações

O homem sé pressuposto como conhecido

O homem é imutável
O palco relata a ação

Observação (desperta sua atividade)

Obriga o espectador a tomar decisões

Concepção de mundo

O espectador é contraposto à ação; é posto em face de, estuda

Trabalha-se com argumentos

As sensações levam a uma tomada de consciência

O homem é objeto de investigação

O homem se transforma e transforma

${ }^{13}$ O quadro é uma compilação das tabelas do próprio Brecht, do Augusto Boal e do Anatol Rosenfeld nos livros Estudos sobre teatro, Teatro do Oprimido e Teatro Épico, respectivamente. Também é possível encontrá-lo no Wikipédia. 
Tensão visando ao desfecho

Organismo (uma cena existe em função da seguinte)

Acontecer linear

Necessidade evolutiva

O mundo tal como é

O homem como ser fixo

Seus impulsos

O pensamento determina o ser

Emoção

\section{Formas do desengano}

Tensão visando o desenvolvimento

Montagem (cada cena existe por si mesma)

Em curvas

Saltos

O mundo tal como se transforma

O homem como processo

Seus motivos

O ser social determina o pensamento

Raciocínio

Imaginar uma linguagem significa imaginar uma forma de vida.

Wittigenstein

Sabe-se que o princípio mediador entre obra arte e sociedade se dá através da forma, em que a realidade é vista por meio da ficção e a ficção por meio da realidade; e que ambas fundam um pêndulo temático que pende ora para um lado, ora para outro de modo a atingir seu teor de verdade social. Mas também podemos analisar o peso de uma obra pela tríade Arte-História-Política, nesse caso, a última funcionando como base do triângulo, denotando a intenção do artista. Seja qual for o ponto de partida (ainda que cada método tenha seu ponto de chegada), no meio do caminho vamos notar que existe uma íntima e tensa correspondência entre a realidade objetiva e a figurada, de modo a desvelar a ideologia, responsável pelo mascaramento da estrutura em que se assentam economia e moral como falsa consciência para reprodução do sistema. Em resumo, ler o mundo através da arte e a arte através do mundo. Nesse sentido, vale dizer que as sete peças reunidas no livro apresentam unidade não somente porque formam um quadro evolutivo da pesquisa do grupo - ou possuem mais ou menos os mesmos temas ainda que em objetos diferentes - mas porque seguem à risca o modelo brechtiano de um passo atrás do presente reificado, caracterizando um mundo pré-mercantil, com vistas a um passo além da realidade paralisante do mundo capitalista. É como se esse 
movimento constituísse como exigência histórica a superação da vida danificada através de uma perspectiva de futuro ${ }^{14}$.

Interessado socialmente, o teatro da Companhia do Latão sublinha que o critério de valores estéticos brechtianos é extraído da perspectiva da luta social cujo sentido político está no modo de organizar suas relações de produção. Assim, o ponto de vista assumido pelo grupo é o da crítica social. Um teatro materialista sem perder o refinamento estético.

Veja o prólogo da peça "Auto dos bons tratos", texto que trata da disputa entre empreendedores e a Igreja pela mão-de-obra dos índios escravizados. Com estudo sobre o capítulo cinco ("O Homem Cordial”) do livro Raízes do Brasil, de Sergio Buarque de Holanda (do qual extrai a crítica do paternalismo que assola o país), a Companhia tenta desmontar a ideologia no momento mesmo que sua constituição daria os primeiros passos no País. Ao apresentar figuras que ainda não foram completamente mercantilizadas na estrutura socioeconômica do Brasil, o texto permite ao mesmo tempo criar a brecha para historicizar as relações de trabalho e dar o passo atrás antes de topar com a sociedade inteiramente fetichizada pela forma-mercadoria. Esse recuo estratégico funciona como efeito político e estético porque crítica e historização passam a ser uma coisa só, de modo que objeto representado e representação interferem um no outro, exigindo um passo além do teatro; imaginação (imagem + ação): tomada de consciência.

Os atores se põem diante dos espectadores

ATRIZ Senhores espectadores, bem-vindos!

Esta peça é uma fábula aos pedaços.

Imaginem um elefante e um rinoceronte

Posto a duelar em praça pública pelo capricho de um antigo.

Imaginem agora a multidão de centopéias, minhocas e lacraias

E toda a plebe dos bichos, esmagada sob a pata dos monstros em luta.

O resultado disso é uma peça despedaçada.

Que nossa ruína se complete

Com a simpatia de sua imaginação.

(Companhia do Latão 7 peças, “Auto dos bons tratos”, p. 148)

\footnotetext{
14 De acordo com o professor José Pasta "em Brecht, e nesse seu remoto modelo, é a perspectiva de futuro, o produzir-se de algo novo que permite chamar à copresença (presentificação e simultaneidade) os sistemas do passado. O seu fazer-se pede que, ante nossos olhos, eles se tornam simultâneos e descrevam suas revoluções recíprocas. Este seu a-presentar-se como que os lega, em conjunto, àquele que deve produzir o novo, e nisto, são o patamar de sua capacidade de ação". PASTA, José Antônio. Trabalho de Brecht, São Paulo: Editora 34, 2010. P. 140.
} 
Outra peça interessante do livro que mantém o caráter crítico do grupo é "A Comédia do Trabalho", texto revelador sobre o modo como o capital age em um país de terceiro mundo.

Sabemos que a estética precede considerações de outra ordem. Com isso, vale ressaltar que as condições sociológicas aqui no Brasil formam uma estrutura anômala em que a miséria é parte constituinte do capitalismo. Essa contradição inerente do mundo do trabalho, a que denominamos dialética do otário e do malandro, gera um movimento em que a lógica exclusão/inclusão da esfera econômica e social torna-se uma unidade formal onde o capital é o todo, ou seja, a exclusão é condição da inclusão. Quanto mais excluído dos meios de produção, mais incluído no capital o trabalhador está. Em suma, o malandro e todos aqueles que antes viviam à margem (outrora conhecidos por “exército de reserva"), em novo jargão sociológico, agora fazem parte da População Economicamente Ativa (PEA), potencial mão-de-obra do setor produtivo. Mais ainda, o fato de estarem "fora" barateia o custo de reprodução da força de trabalho dos que estão "dentro". Esse tipo de equação faz com que o trabalhador tenha como interesse fundamental garantir o emprego. A qualquer momento, refém do humor do mercado, o otário (trabalhador) pode ser o desempregado, e o malandro passa a ser o otário da vez. Essa anomalia (a união entre malandragem e as relações de trabalho) é matriz prática do pressuposto teórico-político que orienta o grupo e o elemento propulsor das formas que vão mediar as relações entre teatro e sociedade.

Entra um grupo de mendigos com seus trapos, e outro de pedintes apoiados em muletas.

MENDIGOS E PEDINTES Uma esmola, meu senhor, uma esmolinha.

Somos sujos, não trocamos de calcinha

Temos feridas sangrentas

E a barriga costurada com uma linha.

Uma esmola, meu senhor, uma esmolinha.

PLÁCIDO [observa o grupo e se aproxima aos poucos] Acho que vou tentar outro trabalho

MENDIGA [aos pedintes] Ouçam todos. A situação está insustentável. Esses desempregados estão começando a atrapalhar a nossa vida de mendigo. Eles chegam à procura de trabalho, não encontram, ficam deprimidos, começam a beber, aí vem com seu cobertorzinho... querem dormir do nosso lado.

MENDIGO Não podemos mais tomar sol nem praticar o amor livre debaixo de nossas caixas de papelão.

MENDIGA Eu não vou acusar ninguém, mas estamos correndo o risco de ser roubados. 
PLÁCIDO [tomando coragem, ao líder dos mendigos] Eu quero uma oportunidade para aprender uma nova profissão. Eu acho que tenho jeito pra coisa.

CORO DE PEDINTES Quem é esse sujeito?

PLÁCIDO Eu só quero um espaço pra desenvolver meu potencial, eu tenho muita criatividade.

MENDIGO Não há vagas.

MENDIGA A situação está crítica.

MENDIGO [em altos brados] Só a união da categoria dos miseráveis pode resolver esse problema.

CORO DE PEDINTES União com quem? Conosco? Nós não somos mendigos. Queremos que vocês morram.

MENDIGA Eles não estão nada amistosos.

PEDINTE 1 [ a Plácido] Ei rapaz, do nosso lado você não tem vez.

PEDINTE 2 Nós pedintes pertencemos a outra categoria

CORO DOS PEDINTES Temos habilidade, hierarquia, sabemos abordar o cliente. Somos superiores aos mendigos.

MENDIGOS Então vão tomar nos seus cus.

(Companhia do Latão 7 peças, “A comédia do trabalho”, p. 97-98).

\section{O conceito da Dialética e a dialética do Conceito}

No mundo tudo é dissídio e comércio.

Lêdo Ivo.

Marx mostrou que as categorias político-econômicas são abstrações das relações sociais e que essas mesmas relações são resultado de um processo histórico. O que Brecht fez foi trazer esse postulado para dentro da cena e o contrapor ao modelo aristotélico, ao drama rigoroso, que tomava as relações como naturais sem perceber as determinantes sociais dessas mesmas relações. Na acepção de Anatol Rosenfeld,

“[...] o encadeamento rigoroso da Dramática pura, o qual sugere a situação irremediavelmente trágica do homem, devido ao envolver inexorável da ação linear, é substituído pelo salto dialético. Esta estrutura em curvas permite entrever, em cada cena, a possibilidade de um comportamento diverso do adotado pelos personagens, de acordo com situações e condições diversas".

(ROSENFELD, Anatol. O Teatro Épico. São Paulo: Perspectiva, 2004. P. 150)

Pois bem, o que a Companhia do Latão faz a partir disso está artisticamente composto nos capítulos três capítulos do livro. Tanto em "Imagens do Brasil" quanto em "Cenas da mercantilização", o grupo parece pensar a atualidade de Brecht no movimento desigual e combinado do capital, sobretudo, de alguém que enuncia seu 
ponto de vista na periferia do capitalismo onde as contradições sociais são mais evidentes. Mas aí surge o problema: se o distanciamento ${ }^{15}$ é o efeito de desfamiliarização da realidade - uma maneira de fazer o espectador tomar consciência do problema como um resultado histórico - qual seria hoje seu sentido e poder de alcance em um mundo que a economia subiu para primeiro plano, que a formamercadoria forja a própria realidade sem precisar esconder o rosto? Nas palavras de Adorno a ideologia é hoje sociedade tal como ela aparece, quer dizer, o gestus que apontava para o caráter mistificador da realidade parece esvaziado de seu conteúdo substancial, de mostrar as reais forças em jogo. Com a queda do socialismo e o triunfo do capitalismo, a dialética vê seu processo interrompido e assiste passivamente a tirania do idêntico se alastrar como forma real de compreensão das coisas. "Noutras palavras, o distanciamento artístico parece desvitalizado pelas circunstâncias: que mais quer o materialista se há mercadorias à escolha e se a engrenagem mercantil integra a todos? Essa objeção, que tem (ou teve?) o apoio do dia-a-dia nos países em que o salário e a previdência social integraram a classe trabalhadora, está por trás da transformação de Brecht em clássico, quer dizer, em gentil escritor de outras eras". ${ }^{16}$ Ora, deve-se tomar cuidado com a armadilha retórica do texto pra não ficar entre a paralisia e a aporia. Desde Beckett sabemos que a "imobilidade é a forma negativa de integração" e que um inconformismo conformista apenas sublinha o que aí está. Porém, vale ressaltar que também soa ingênuo a ideia brechtiana de que "nossas esperanças estão na contradição". É certo que com o sinal verde da história para o capitalismo a cultura se desfragmentou e seus pedaços estão espalhados nas diferentes divisões do trabalho das outras esferas da existência. Mas é igualmente certo que só repensando a cultura nas suas bases e duvidando dos diagnósticos fatalistas que a arte poderá reorganizar o espírito da contradição. Caso contrário, "pode-se colocar solitariamente nas ameias de

15 “A teoria do distanciamento é, em si mesma, dialética. O tornar estranho, o anular da familiaridade da nossa situação atual, a ponto de ela ficar estranha a nós mesmo, torna, mais elevado esta nossa situação conhecida e mais familiar. O distanciamento passa então a ser a negação da negação; leva através do choque do não-conhecer ao choque do conhecer. Trata-se de um acúmulo, de incompreensibilidade até que surja a compreensão. Tornar estranho é, portanto, ao mesmo tempo tornar conhecido. A função do distanciamento é a de se anular a si mesma”. JAMESON, Fredric. O Método Brecht. Petrópolis: Editora Vozes, 1999. P. 152.

16 SCHWARZ, Roberto. "Atualidade de Brecht" in Seqüencias brasileiras: ensaios. São Paulo: Companhia das Letras, 1999. Para outra opinião conferir o ensaio da professora Iná Camargo Costa, "Brecht, Adorno e o interesse do engajamento" in Capítulos do Marxismo Ocidental. São Paulo: Editora Unesp, 1998. 
uma produção extremada, criticando aniquiladoramente todo o existente, desde que, como conformista-não conformista bem educado, nada se faça que implique jogar areia na máquina manipuladora”, como respondeu Lukács a Adorno. E o paradoxo reside aí. Os mesmos que defendem que o Capital agora é o todo criticam qualquer atitude que tente juntar os cacos para reativar a disposição totalizante de um projeto como o de Brecht. Mais ainda, o possível anacronismo do Método Brecht, que exige um passo atrás da condição de fetiche da mercadoria a que chegou o mundo, talvez seja justamente a forma de superar os impasses da crise da representação, ou seja, pensando como Bloch, fazer o "não-contemporâneo" vibrar na espinhal dorsal da lógica pós-moderna. Atualizar dialeticamente o mecanismo que denuncia a feição moderna das práticas arcaicas que fomentam a estrutura brasileira. Esse olhar às avessas, que paralisa o instante como imagem fixada da história e faz bater o "arcaico no coração do moderno" mostra que refletir sobre a atualidade de Brecht e o potencial crítico da dialética implica uma verificação do estado de mundo onde a própria pergunta é uma exigência histórica e pede uma recapitulação dos processos políticos e culturais sob os quais se erguem as bases desse novo capitalismo. Talvez a última cena da peça Visões Siamesas coloque os pingos nos “i(s)" e retome o problema em sua formulação estética.

O palco está vazio. A luz no chão reforça a imagem das areias no deserto na noite escura. À frente estão Kinara e o rei kalafanko. Ao fundo, um grande coro de atores.

\section{ATRIZ QUE REPRESENTA KINARA [ao público]}

A última cena da peça, a mais abstrata, é escancaradamente materialista. Ela exprime uma integração total, perversa. De um lado, restos humanos do trabalho informal, a caminho do nada. Um anúncio do futuro do ocidente. Do outro, voluntarismo e fatalismo, e o embotamento da vontade de agir coletivamente.

ATOR QUE REPRESENTA KALAFANKO Morre no deserto o corpo de Kinara na alma de Kalafanko. Morre no palácio a alma de Kinara no corpo de Kalafanko.

Kinara grita e toma o cajado do rei. Parece lutar com inimigos invisíveis. Ao fundo, o grande Coletivo dos Despossuídos observa a cena.

ATOR-KALAFANKO Rei Kalafanko do Sião! Desiste de uma ação inútil. Abandona a salvação de todos e goza! Solitariamente, goza!

ATRIZ-KINARA Eu não ouço mais nada! Eu não preciso de ninguém e me ofereço sozinho ao sacrifício.

Degola-se ironicamente com o cajado, grita.

ATOR-KALAFANKO Rei Kalafanko do Sião! Corrige a tua miragem. Transforma as areias do deserto no piso do palácio. Uma mulher muito branca te dará um beijo na testa e te livrará de toda a culpa. 
ATRIZ-KINARA Eu não acredito na morte! Eu realizo o meu destino. E imponho ao império a minha glória imortal.

ATOR-KALAFANKO Rei Kalafanko de Sião! Mártir do individualismo. Sem exército. Sem lacaios. Seu um povo com quem se identificar. Se me fosse permitido, eu própria te mataria. Mas se eu te matasse, quem morreria?

Olham-se. Ela fica menos agitada.

ATRIZ-KINARA Por que sé me ensinaram a sonhar no singular?

(Companhia do Latão 7 peças, "Visões Siamesas", P. 324-325).

\section{Questão de método e o chão da fricção}

Perante um obstáculo, a linha mais curta entre dois pontos pode ser a curva.

Bertolt Brecht

Descritos alguns dos aspectos gerais do teatro dialético da Companhia do Latão, a partir de seus textos reunidos no livro, vale comentar o prefácio da professora e crítica teatral Iná Camargo Costa. Além do belo painel que ela compõe sobre o lugar do grupo no teatro brasileiro, sublinhando seus interesses e seus vínculos, há apontamentos de ordem metodológica sobre a posição que o pensamento dialético ocupa na batalha das ideias. Para Fredric Jameson, a diferença entre a dialética e outros métodos não está apenas nas considerações finais a que chega - o resultado do conceito como apreensão da realidade - mas também, e principalmente, na evolução de cada passo em direção a outro, de cada pergunta tomada como resposta, elevando o pensamento na busca pelo todo na medida em que o próximo passo é sempre uma recapitulação dos anteriores.

Em outras palavras, visa, não tanto resolver os dilemas particulares em questão, mas converter esses problemas em soluções num nível mais elevado, e fazer do fato e da própria existência do problema o ponto de partida para uma nova investigação. Este é, na verdade, o momento mais delicado no processo dialético: aquele no qual todo um complexo de pensamento é içado, por meio de uma espécie de alavanca interna, um andar acima; momento no qual a mente, numa espécie de mudança de marcha, encontra-se pronta a tomar por resposta o que tinha sido uma pergunta, pondo-se fora de seus esforços anteriores de modo a reconhecer-se no problema, compreendendo o dilema não apenas como uma resistência do objeto, mas também como resultado do pólo do sujeito, desdobrado e colocado de maneira estratégica - em suma, com uma função de uma determinada relação sujeito-objeto.

(JAMESON, Fredric. Marxismo e Forma. São Paulo: Hucitec, 1985, p. 236)

Portanto, quando a professora assume a postura de criticar frontalmente a lógica, acusando-a de ser a guardiã da ordem, não o faz tomada por um sentimento gratuito de 
atacar tudo a sua volta, mas de quem sabe que o pensamento lógico funciona como um "relato de legitimação" da realidade e constitui a base para uma epistemologia de direita.

Nos termos de Sartre, uma filosofia se constitui para dar expressão ao movimento geral da sociedade, "caracteriza-se como um método de investigação e explicação; a confiança que tem em si mesma e em seu desenvolvimento futuro limitase a reproduzir as certezas da classe que a sustenta" ${ }^{17}$.

Para ele, entre os séculos XVII e XX, três são os momentos em que a filosofia atinge uma totalização do Saber, é método e Ideia reguladora. O momento de Descartes e Locke, Kant e Hegel, e, por fim, Marx. Esses momentos tornam-se, cada qual por sua vez "o Humus de todo pensamento particular e o horizonte de toda a cultura, eles são insuperáveis enquanto o momento histórico de que são expressão não tiver sido superado". E continua

"Com frequiência tenho observado o seguinte: um argumento antimarxista não passa do rejuvenescimento de uma ideia pré-marxista. Uma pretensa superação do marxismo limitar-se-á, na pior das hipóteses, a um retorno ao pré-marxismo e, na melhor, à redescoberta de um pensamento já contido na filosofia que se acreditou superar. Quanto ao 'revisionismo', trata-se de um truísmo ou de um absurdo: não há motivo para readaptar uma filosofia viva ao curso do mundo; por si mesma, ela opera tal adaptação através de mil iniciativas, mil pesquisas particulares, porque está intimamente ligada ao movimento da sociedade. Aqueles que se julgam os porta-vozes mais fiéis de seus predecessores, apesar da boa vontade, transformam os pensamentos que pretendem simplesmente repetir; os métodos modificam-se porque são aplicados a objetos novos. Se esse movimento da filosofia já não existe, das duas uma: ou ela está morta ou, então, está 'em crise'. No primeiro caso, não se trata de rever, mas de demolir um edifício condenado; no segundo caso a 'crise filosófica' é a expressão particular de uma crise social e seu imobilismo é condicionado pelas contradições que dilaceram a sociedade[...]” ${ }^{18}$.

Partindo do pressuposto de que não existe um lugar axiologicamente neutro, Iná Camargo Costa opõe as fases da dialética aos três momentos da lógica. Assim, na concepção da professora, a lei da passagem à quantidade, lei da interpenetração dos contrários e finalmente a lei da negação da negação são mais efetivos que os princípios da identidade, da contradição e do terceiro excluído. Para ela

"na dialética, o princípio de identidade não só não é revogado como ainda é reconhecido como necessário à progressão das categorias e conceitos, à medida que as contradições vão sendo ultrapassadas e incorporadas ao conhecimento de cada um deles. O que a dialética recusa é a aplicação unilateral da categoria isolada - pois isto significa evitar, negligenciar e assim tornas insolúveis as contradições. A

17 SARTRE, Jean-Paul. Crítica da razão dialética. Rio de Janeiro: DP\&A, 2002. P. 20.

18 Idem, P. 21 
identidade é apenas o primeiro termo, o simples, o imediato, o ponto de partida. Seu conhecimento só é alcançado através da mediação que implica diferença, oposição e contradição. A ideologia lógica simplesmente justapõe a semelhança e a diferença e, sem compreender a transição de uma determinação pra outra, conserva-se na tautologia vazia. Nos casos mais avançados, ela no máximo chega até aos 'por um lado... por outro' e aos 'na medida em que', sem se dar conta da inseparabilidade dos termos". (Companhia do Latão 7 peças, "A comédia do trabalho", p. 20-21).

Ora, crer que exista uma "harmonia essencial entre pensamento, linguagem e realidade" desconsiderando o caráter ideológico da vida, os fundamentos econômicos que a estruturam, é corroborar "uma fase na qual a irracionalidade e a falsidade objetiva se escondem atrás da racionalidade e da necessidade objetiva e a aparência tornou-se total"19. A lógica, enquanto forma essencial do pensamento e do discurso, quando sente que seus alicerces estão estremecidos parece negar que toda proposição é intencional, ou seja, que tem um sentido político e não apenas contingencial (verdadeiro ou falso). Aliás, é justamente na bipolaridade da proposição que verificamos os reais interesses por trás de seus argumentos. Afinal, uma mudança epistemológica da posição do sujeito reflete uma mudança ontológica do objeto. Assim, a filosofia permanecerá eficaz enquanto viver a práxis que a engendrou, a sustenta e é por ela iluminada.

Nesse sentido, é preciso reconhecer que há uma mediação inerente entre homem e mundo, entre sujeito e objeto; e na filosofia, assim como na vida, a ideia de “opacidade intransponível” é muito mais um capricho teológico da mercadoria (afirmar o que as coisas são, rejeitando que elas somente são a partir do que não sejam), é menosprezar - por descuido ou por desleixo, cinismo ou ingenuidade - a capacidade de inteligibilidade do sujeito do conhecimento atestando a atitude conservadora da análise, valorizando a filosofia apenas como método especulativo e descartando seu potencial político, de verificador da verdade.

Ignorar o tende a ser da História é esvaziar o conteúdo utópico do pensamento (a consciência antecipadora ou "ainda-não-consciente" na terminologia de Bloch), é aceitar o mundo tal como ele aparece e descartar o que ele poderia ser. Além de empobrecer a forma de análise denota uma postura política do observador.

Todo mundo deveria saber que a lógica, por ser a expressão e o método da ideologia dominante (a guardiã da ordem) é a mais ferrenha inimiga da dialética. E não apenas porque não a entende nem tem condições de entender, mas sobretudo porque seus cultores perceberam, desde a primeira metade do século XIX, que o pensamento dialético é uma ferramenta mortal nas mãos de seu inimigo de classe, o inimigo (e vítima) da ordem. Mas há razões internas, de método, para que os lógicos desfigurem e

19 ADORNO, Theodor. Primas: crítica cultural e sociedade. São Paulo: Editora Ática, 1998. P. 17 
caricaturem a dialética, que vão além da estratégia de desmoralizar a contradição. Eles sabem que a contradição como conceito e, como demonstrou Hegel, como motor do movimento do pensamento, pode ser considerada a própria essência da dialética. Uma razão interna é o caráter dogmático do campo lógica: ela opera por definições, estabelece princípios, regras, etc. sem nunca submeter seus próprios termos a qualquer tipo de exame crítico. Assim é que, para um lógico, a oposição entre verdadeiro e falso, é evidente por si mesma e dispensa explicações. Digamos que essa operação demarca o terreno que interessa para um lógico: atribuir (ou calcular, no caso da lógica simbólica) os valores de verdade ou falsidade das proposições ou enunciados. Mas, para chegar aí, é preciso percorrer o caminho que vai dos conceitos à construção das proposições. (Companhia do Latão 7 peças, "Auto dos bons tratos”, p. 18)

O que a professora e crítica Iná Camargo Costa faz no prefácio é uma atitude crítica no sentido brechtiano, corajosa, de enfrentamento político com um tema espinhoso, sempre mantendo clara sua posição no momento em que coloca pra exame os pressupostos teóricos dos adversários. Ao lembrar o que alguns preferem esquecer, iluminar o que outros querem deixar no escuro, ela vai além da atitude brechtiana. Ela fala de corda em casa de enforcado. 